\title{
PERUBAHAN KOMPONEN SERAT RUMPUT LAUT Caulerpa sp. (DARI TUAL, MALUKU) AKIBAT PROSES PEREBUSAN
}

\section{THE CHANGE IN FIBER COMPONENTS OF Caulerpa Sp. SEAWEEDS (FROM TUAL OF MALUKU) DUE TO BOILING PROCESS}

\author{
Nurjanah $^{1}$, Agoes Mardiono Jacoeb ${ }^{1}$, Taufik Hidayat ${ }^{2 *}$, dan Rudy Chrystiawan ${ }^{1}$ \\ ${ }^{1}$ Departemen Teknologi Hasil Perairan, FPIK-IPB \\ ${ }^{2}$ Pusat Teknologi Agroindustri Jalan Raya Puspiptek, LAPTIAB BPPT \\ *E-mail:besthd22@gmail.com
}

\begin{abstract}
Caulerpa sp. seaweeds are known as a source of fiber. The seaweeds are found on the coasts of Indonesia, such as Tual, Southeast Maluku. Caulerpa sp. is often consumed at fresh or boiled first by coastal communities. Boiling aim to inactivate the enzymes and to reduce the number of microbes, however the treatment it is feared could affect the components of fiber contained in seaweed. The purpose of this study was to determine changes in levels of dietary fiber (soluble and insoluble dietary fiber), crude fiber, and fiber components (cellulose, hemicellulose, lignin) as a result of the boiling process at a temperature of $90^{\circ} \mathrm{C}$ for 5 minutes. Analytical tests performed, including proximate analysis, carbohydrates method Luff schoorl, dietary fiber method of enzymatically, crude fiber, and fiber components (cellulose, hemicellulose, lignin). The results showed that boiling did not affect the lignin content. In addition, boiling increased the levels of insoluble dietary fiber $1.25 \%$, cellulose $13.91 \%$, hemicellulose $11.4 \%$ and, decreased the levels of total dietary fiber $3.8 \%$, soluble dietary fiber $5.05 \%$, and crude fiber $0.85 \%$.
\end{abstract}

Keywords: Caulerpa sp., fiber components, Tual city

\begin{abstract}
ABSTRAK
Rumput laut Caulerpa sp. dikenal sebagai sumber serat. Rumput laut Caulerpa sp. banyak ditemukan di pesisir pantai Indonesia, salah satunya di perairan Tual, Maluku Tenggara. Rumput laut ini sering dikonsumsi segar oleh masyarakat pesisir ataupun direbus terlebih dahulu. Perebusan bertujuan untuk menginaktifkan enzim dan menurunkan jumlah mikroba, namun dikhawatirkan dapat mempengaruhi komponen serat yang terkandung pada rumput laut. Penelitian ini bertujuan untuk menentukan perubahan kadar serat pangan (serat pangan larut dan tak larut), serat kasar, dan komponen serat (selulosa, hemiselulosa, lignin) akibat proses perebusan pada suhu $90^{\circ} \mathrm{C}$ selama 5 menit. Analisis uji yang dilakukan, diantaranya analisis proksimat, kadar karbohidrat metode Luff schoorl, serat pangan metode enzimatis, serat kasar, dan komponen serat (selulosa, hemiselulosa, lignin). Hasil penelitian menunjukkan perebusan tidak mempengaruhi kadar lignin. Perebusan meningkatkan kadar serat pangan tak larut $1,25 \%$, selulosa $13,91 \%$, hemiselulosa $11,4 \%$, dan menurunkan kadar serat pangan total 3,8\%, serat pangan larut 5,05\%, dan serat kasar $0,85 \%$.
\end{abstract}

Kata kunci: Caulerpa sp., komponen serat, kota Tual

\section{PENDAHULUAN}

Indonesia sebagai negara maritim dan memiliki sumberdaya perairan cukup besar yang belum dimanfaatkan secara optimal, salah satunya adalah rumput laut. Rumput laut yang digunakan dalam penelitian adalah
Caulerpa sp. dari perairan Tual, Maluku Tenggara. Jumlah produksi rumput laut di daerah Tual, Maluku Tenggara terus mengalami peningkatan, pada tahun 2009 sebesar 3.285 ton, tahun 2010 sebesar 4.872,9 ton, tahun 2011 sebesar 7.947,4 ton, dan tahun 2012 sebesar 8.953,32 ton rumput 
laut kering (BPS, 2013). Rumput laut hijau di Indonesia terdapat 203 spesies, yang terdiri dari 7 ordo, 19 famili, dan 48 genus. Salah satu genusnya yakni Caulerpa terdiri dari 34 spesies (Atmadja dan Willem, 2011).

Rumput laut Caulerpa racemosa dapat dikonsumsi sebagai sayuran segar atau lalapan. Rumput laut ini juga dikonsumsi mentah sebagai lalapan atau dijadikan urap oleh masyarakat pesisir di bagian utara pulau Jawa, khususnya di Jawa Tengah yaitu di Jepara, Pati, Juwana, dan Rembang, namun masyarakat pesisir di Bali umumnya mengonsumsi rumput laut ini dengan cara direbus terlebih dahulu. Santoso et al. (2004) menyatakan bahwa rumput laut yang dapat dikonsumsi mengandung insoluble dietary fiber (serat makanan tak larut) yang terdiri dari selulosa dan hemiselulosa. Burtin (2003) menyatakan bahwa kandungan serat rumput laut mencapai $30-40 \%$ berat kering. Menurut Matanjun et al. (2009), rumput laut Caulerpa lentillifera dari perairan Semporna, Malaysia mengandung serat pangan total $32,99 \pm$ $2,07 \%$, serat larut $17,21 \pm 0,87 \%$, dan serat tak larut 15,78 $\pm 1,20 \%$. Sanchez et al. (2004) menyatakan bahwa kandungan karbohidrat pada rumput laut umumnya berbentuk serat yang tidak bisa dicerna oleh enzim pencernaan manusia, sehingga hanya memberikan sedikit asupan kalori dan cocok sebagai makanan diet. Menurut Riyanto dan Wilakstanti (2006) menyatakan bahwa cookies rumput laut mempunyai nilai serat kasar 1,44-1,58\% dan nilai serat makanan 5,98-6,02\%, sedangkan Nurjanah et al. (2015) juga menyatakan Caulerpa sangat potensial sebagai sumber serat dari aspek pangan dan aspek non pangan untuk pembuatan kosmetik. Selain untuk serat, rumput laut juga diketahui sangat bermanfaat untuk sumber pangan maupun non pangan diantaranya sebagai sumber garam (Nurjanah et al., 2018; Nufus et al., 2017; Diachanty et al., 2017), sebagai sumber bahan baku kosmetik (Luthfiyana et al., 2016; Maharani et al., 2017; Yanuarti et al., 2017; Dolorosa et al., 2017; Nurjanah et al., 2017).

Menurut hasil penelitian Ortiz et al. (2006) menyatakan bahwa rumput laut dikenal sebagai sumber serat dan dapat digunakan sebagai makanan fungsional untuk mencegah obesitas dan penyakit degeneratif. Penyakit degeneratif disebabkan oleh akibat kurangnya konsumsi serat, diantaranya hipertensi, stroke, obesitas, jantung koroner, dan diabetes melitus. Prevalensi penyakit degeneratif di Indonesia semakin meningkat, diantaranya prevalensi hipertensi pada penduduk umur 18 tahun keatas 31,7\%. Prevalensi nasional obesitas penduduk umur 15 tahun keatas $10,3 \%$, prevalensi stroke $8,3 \%$, prevalensi penyakit jantung $7,2 \%$, dan prevalensi diabetes melitus 1,1\% (DEPKES, 2008). Konsumsi serat di Indonesia hanya 10,5 g per hari. Konsumsi serat di Indonesia masih dibawah anjuran gizi, yaitu 20-35 g per hari. Menurut Anderson et al. (2009), asupan serat dapat memberikan manfaat bagi kesehatan, diantaranya dapat menurunkan risiko terjadinya penyakit jantung koroner, stroke, diabetes melitus, obesitas, gangguan pencernaan, menurunkan tekanan darah tinggi, dan mengendalikan kadar gula darah.

Salah satu potensi rumput laut Caulerpa sp. yakni sebagai sumber serat. Penelitian sebelumnya mengenai kandungan serat pangan total rumput laut Caulerpa racemosa dan Caulerpa sertularoides dari Pulau Seribu, Jakarta, yang dilakukan Santoso et al. (2004) menunjukkan hasil $64,9 \pm 4,9 \%$ dan $61,8 \pm 1,1 \%$, namun informasi mengenai komponen serat Caulerpa sp. akibat proses perebusan belum dilaporkan. Proses perebusan dapat menginaktifkan enzim dan menurunkan jumlah mikroba, namun dikhawatirkan dapat mempengaruhi komponen serat yang terkandung pada rumput laut tersebut. Penelitian ini bertujuan untuk menentukan perubahan serat pangan (seat pangan larut dan tak larut), serat kasar, dan komponen serat (selulosa, hemiselulosa, lignin) akibat proses perebusan. 


\section{METODE PENELITIAN}

\subsection{Bahan dan Alat}

Bahan dan alat yang digunakan adalah rumput laut Caulerpa sp. dari perairan Tual, air mineral merk, larutan n-heksana (Emsure), $\mathrm{Pb}$ asetat (Emsure), $\mathrm{Na}_{2} \mathrm{HPO}_{4}$ (Emsure), $\mathrm{Na}_{3} \mathrm{PO}_{4}$ (Emsure), larutan Luff Schoorl, petroleum eter (Emsure), buffer natrium fosfat (Emsure), enzim termamyl (Sigma), enzim pepsin (Sigma), enzim pankreatin (Sigma), etanol (Emsure), aseton (Emsure). Alat yang digunakan dalam penelitian ini meliputi gelas ukur $100 \mathrm{~mL}$ (Pyrex), gelas piala $2 \mathrm{~L}$ (Herma), oven (Memmert), desikator, tabung sokhlet, dan tanur (Memmert).

\subsection{Prosedur Penelitian}

Penelitian dilakukan untuk menentukan perubahan komponen serat rumput laut Caulerpa sp. akibat proses perebusan. Penelitian ini dilakukan sebanyak tiga kali ulangan. Sampel yang sudah dipreparasi kemudian dianalisis proksimatnya, meliputi kadar air, abu, lemak, protein dengan metode AOAC (2005), kadar karbohidrat dengan metode by difference dan metode Luff Schoorl, dan dilakukan uji serat pangan (serat pangan larut dan tak larut) dengan metode Asp et al. (1992), uji serat kasar dengan metode AOAC (1995), serta uji komponen serat (selulosa, hemiselulosa, dan lignin) dengan metode Van Soest (1963).

\subsection{Proses Perebusan}

Sampel Caulerpa sp. rebus diperoleh dengan cara merebus menggunakan air mineral dengan perbandingan rumput laut 4:1 pada suhu $90^{\circ} \mathrm{C}$ selama 5 menit dalam kondisi gelas piala terbuka. Mekanisme perebusan yakni air mineral dimasukkan dalam gelas piala berukuran $2 \mathrm{~L}$, kemudian dimasak menggunakan kompor listrik, setelah suhu air $90^{\circ} \mathrm{C}$, kemudian ditambahkan rumput laut. Perebusan selama 5 menit dihitung setelah penambahan rumput laut (Putera, 2015).

\subsection{Prosedur Analisis}

\subsubsection{Analisis Proksimat (Kadar Air, Protein, Abu, Lemak Berdasarkan \\ (AOAC, 2005))}

\subsubsection{Analisis Kadar Karbohidrat}

Metode Luff Schoorl (Sulaeman et al., 1993)

Sampel rumput laut baik segar dan melalui proses perebusan $5 \mathrm{~g}$ dilarutkan dengan akuades hingga $100 \mathrm{~mL}$ melalui pengenceran, kemudian diambil $50 \mathrm{~mL}$ air larutannya dan dimasukkan ke dalam labu ukur $500 \mathrm{~mL}$, kemudian ditambah $10 \mathrm{~mL} \mathrm{~Pb}$ asetat 5\% (pH 9,3) lalu dikocok, kemudian larutan tersebut ditambah 4 tetes $\mathrm{Na}_{2} \mathrm{HPO}_{4}$ $10 \%$, apabila terdapat endapan putih berarti $\mathrm{Pb}$ asetat sudah cukup, kemudian ditambah 6 tetes $\mathrm{Na}_{3} \mathrm{PO}_{4} \quad 10 \%$ sampai tidak terbentuk endapan putih lagi. Larutan ditera dengan akuades, kemudian disaring dengan kertas saring Whatman No.42 dan didiamkan selama 30 menit. Filtrat diambil sebanyak 10 $\mathrm{mL}$ dan dimasukkan ke dalam labu ukur 100 mL kemudian ditambah $5 \mathrm{~mL} \mathrm{HCl} \mathrm{25 \%} \mathrm{dan}$ dipanaskan dalam water batch pada suhu $70^{\circ} \mathrm{C}$ selama 10 menit, setelah dingin larutan dinetralkan dengan $5 \mathrm{~mL} \mathrm{NaOH} 30 \%$ dan ditambah 2 tetes indikator fenolftalein 1\% sampai berwarna merah jambu. Cairan diambil $10 \mathrm{~mL}$, ditambah $15 \mathrm{~mL}$ akuades, 25 $\mathrm{mL}$ larutan luff schoorl dan batu didih. Larutan dipanaskan dalam water batch pada suhu $70^{\circ} \mathrm{C}$ selama 10 menit dan dibiarkan dingin, kemudian ditambah $10 \mathrm{~mL}$ KI 30\%, $25 \mathrm{~mL} \mathrm{H}_{2} \mathrm{SO}_{4} \quad 25 \%$. Kemudian dititrasi dengan $\mathrm{Na}_{2} \mathrm{~S}_{2} \mathrm{O}_{3} \quad 0,1 \mathrm{~N}$ menggunakan $2 \mathrm{~mL}$ indikator kanji 1\%. Titrasi dilakukan sampai warna biru tidak terbentuk lagi. Larutan blanko dibuat dari $25 \mathrm{~mL}$ akuades ditambah $25 \mathrm{~mL}$ larutan luff schoorl dan batu didih yang dipanaskan hingga mendidih selama 10 menit dan didiamkan hingga dingin. Larutan kemudian ditambah $10 \mathrm{~mL}$ KI 30\%, $25 \mathrm{~mL}$ $\mathrm{H}_{2} \mathrm{SO}_{4} 25 \%$, kemudian dititrasi dengan $\mathrm{Na}_{2} \mathrm{~S}_{2} \mathrm{O}_{3} 0,1 \mathrm{~N}$ menggunakan $2 \mathrm{~mL}$ indikator kanji $1 \%$. Titrasi dilakukan sampai warna biru tidak terbentuk lagi. Larutan luff schoorl dibuat dengan melarutkan 143,8 g $\mathrm{Na}_{2} \mathrm{CO}_{3}$ 
anhidrat ke dalam $300 \mathrm{~mL}$ akuades sambil diaduk dan ditambah $50 \mathrm{~g}$ asam sitrat monohidrat yang dilarutkan ke dalam $50 \mathrm{~mL}$ akuades. Larutan kemudian ditambah $25 \mathrm{~g}$ $\mathrm{CuSO}_{4} .5 \mathrm{H}_{2} \mathrm{O}$ yang dilarutkan ke dalam 100 $\mathrm{mL}$ akuades, kemudian campuran larutan tersebut dipindahkan ke dalam labu ukur $1 \mathrm{~L}$ dan ditera dengan akuades dan dikocok. Kadar karbohidrat ditentukan dengan rumus:

$x=\frac{\text { Blanko }- \text { contoh }}{0,1} \times \mathrm{N} \mathrm{N}_{2} \mathrm{~S}_{2} \mathrm{O}_{3}$

Kadar karbohidrat total $(\%)=\frac{X . Y}{a} \times 100 \%$

Keterangan : $\mathrm{X}=$ Nilai pada tabel luff schoorl, $\mathrm{Y}=$ Faktor pengenceran, $\mathrm{a}=$ Berat sampel (mg).

\subsubsection{Analisis Serat Pangan Metode Enzimatis (Asp et al., 1992)}

Sampel segar dan rebus dikeringkan dengan oven pada suhu $60^{\circ} \mathrm{C}$ selama 21 jam. Sampel kering sebanyak $2 \mathrm{~g}$ diekstrak lemaknya dengan pelarut petroleum eter pada suhu kamar selama 15 menit kemudian sampel dimasukkan ke dalam oven selama 12 jam pada suhu $105^{\circ} \mathrm{C}$. Sampel sebanyak $1 \mathrm{~g}$ (w) dimasukkan ke dalam erlenmeyer 500 $\mathrm{mL}$, kemudian ditambah $25 \mathrm{~mL}$ buffer natrium fosfat $0,1 \mathrm{M}$ dengan $\mathrm{pH} 6$, kemudian ditambah $0,1 \quad \mathrm{~mL}$ enzim $\alpha$-amylase (termamyl) dan ditutup alumunium foil dan diinkubasi pada suhu $100^{\circ} \mathrm{C}$ selama 15 menit, kemudian ditambah $20 \mathrm{~mL}$ akuades dan $\mathrm{pH}$ diatur menjadi 1,5 dengan menambahkan $\mathrm{HCl} 4 \mathrm{M}$, kemudian ditambah $100 \mathrm{mg}$ pepsin, ditutup alumunium foil dan diinkubasi pada suhu $40^{\circ} \mathrm{C}$ dan diagitasi selama 60 menit dan ditambah $20 \mathrm{~mL}$ akuades dan $\mathrm{pH}$ diatur menjadi 6,8; kemudian ditambah $100 \mathrm{mg}$ pankreatin, ditutup alumunium foil dan diinkubasi pada suhu $40^{\circ} \mathrm{C}$ dan diagitasi selama 60 menit, kemudian $\mathrm{pH}$ diatur dengan $\mathrm{HCl} 4 \mathrm{M}$ menjadi 4,5 M. Larutan kemudian disaring dengan cawan kaca masir G3 yang telah ditimbang bobotnya dan dicuci dua kali dengan akuades.

Residu dicuci dengan $2 \times 10 \mathrm{~mL}$ etanol $78 \%$ dan $2 \times 10 \mathrm{~mL}$ aseton, dikeringkan dalam oven pada suhu $105^{\circ} \mathrm{C}$ selama $12 \mathrm{jam}$, dan dimasukkan ke dalam desikator dan ditimbang $\left(D_{1}\right)$, kemudian diabukan dalam tanur pada suhu $500^{\circ} \mathrm{C}$ selama 5 jam, dan dimasukkan ke dalam desikator dan ditimbang $\left(\mathrm{I}_{1}\right)$.

Volume filtrat diatur dengan menambahkan akuades sampai $100 \mathrm{~mL}$, kemudian ditambah $400 \mathrm{~mL}$ etanol $78 \%$ hangat (suhu $60^{\circ} \mathrm{C}$ ), diendapkan 1 jam. Larutan kemudian disaring menggunakan cawan kaca masir G3 dan dicuci dengan $2 \times 10 \mathrm{~mL}$ etanol $78 \%$, $2 \times 10 \mathrm{~mL}$ aseton, dan dikeringkan dalam oven selama 12 jam pada suhu $105^{\circ} \mathrm{C}$, kemudian dimasukkan ke dalam desikator dan ditimbang $\left(\mathrm{D}_{2}\right)$. Ekstrak kering kemudian diabukan dalam tanur pada suhu $500^{\circ} \mathrm{C}$ selama 5 jam, dan dimasukkan ke dalam desikator dan ditimbang $\left(\mathrm{I}_{2}\right)$.

Serat makanan total ditentukan dengan menjumlahkan nilai SDF dan IDF. Nilai blanko untuk IDF dan SDF diperoleh dengan cara yang sama, namun tanpa menggunakan sampel $\left(\mathrm{B}_{1}\right.$ dan $\left.\mathrm{B}_{2}\right)$. Kadar serat ditentukan dengan rumus:

Nilai IDF $(\%)=\left(\left(\mathrm{D}_{1}-\mathrm{I}_{1}-\mathrm{B}_{1}\right) / \mathrm{w}\right) \times 100 \%$

Nilai SDF $(\%)=\left(\left(D_{2}-I_{2}-B_{2}\right) / w\right) \times 100 \%$

Nilai TDF $(\%)=$ Nilai IDF + SDF .

\subsubsection{Analisis Kadar Serat Kasar (AOAC,1995)}

Sampel segar dan rebus dikeringkan dengan oven pada suhu $60^{\circ} \mathrm{C}$ selama 21 jam. Sampel kering sebanyak $2 \mathrm{~g}$ diekstrak lemaknya dengan pelarut petroleum eter pada suhu kamar selama 15 menit kemudian sampel dimasukkan ke dalam oven selama 12 jam pada suhu $105^{\circ} \mathrm{C}$. Sampel sebanyak $1 \mathrm{~g}$ dimasukkan ke dalam erlenmeyer $500 \mathrm{~mL}$ dan ditambah $100 \mathrm{~mL} \mathrm{H}_{2} \mathrm{SO}_{4} \quad 0,325 \mathrm{~N}$. Campuran tersebut dihidrolisis dalam autoklaf selama 15 menit pada suhu $105^{\circ} \mathrm{C}$, kemudian ditambah $50 \mathrm{~mL} \mathrm{NaOH} \mathrm{1,25} \mathrm{N}$ dan dihidrolisis dalam autoklaf selama 15 
menit pada suhu $105^{\circ} \mathrm{C}$. Larutan kemudian disaring dengan cawan kaca masir G3 yang telah diketahui bobotnya. Cawan kaca masir kemudian dicuci berturut-turut dengan air panas, $25 \mathrm{~mL} \mathrm{H}_{2} \mathrm{SO}_{4} 0,325 \mathrm{~N}$, air panas, dan $25 \mathrm{~mL}$ etanol 78\%. Cawan kemudian dikeringkan dalam oven pada suhu $105^{\circ} \mathrm{C}$ selama 1 jam dan dimasukkan ke dalam desikator dan ditimbang. Kadar serat kasar ditentukan dengan rumus:

Kadar serat kasar $(\%)=\frac{\mathrm{A}-\mathrm{B}}{\mathrm{C}} \times 100 \%$

Keterangan: $\mathrm{A}=$ Berat cawan dan residu kering $(\mathrm{g}), \mathrm{B}=$ Berat cawan kaca masir kosong $(\mathrm{g})$, dan $\mathrm{C}=$ Berat sampel $(\mathrm{g})$.

\subsubsection{Analisis Komponen Serat (Van Soest, 1963)}

\subsubsection{Analisis Kadar Hemiselulosa}

Analisis kadar Neutral Detergent Fiber (NDF) menggunakan larutan NDS (Neutral Detergent Solution). Pembuatan larutan NDS dengan mencampurkan 18,61 g EDTA dan $6,81 \mathrm{~g} \mathrm{Na}_{2} \mathrm{~B}_{4} \mathrm{O}_{7} .10 \mathrm{H}_{2} \mathrm{O}$ ke dalam gelas piala $1 \mathrm{~L}$, kemudian ditambah $30 \mathrm{~g}$ sodium lauril sulfat dalam $20 \mathrm{~mL}$ 2etoksietanol. $\mathrm{Na}_{2} \mathrm{HPO}_{4}$ sebanyak $4,56 \mathrm{~g}$ dimasukkan ke dalam gelas piala lain dan ditambah akuades sedikit demi sedikit, dan dipanaskan hingga larut, kemudian dimasukkan ke dalam campuran sebelumnya dan ditambah akuades hingga volumenya $1 \mathrm{~L}$. Larutan tersebut kemudian diukur $\mathrm{pH}$-nya pada kisaran 6,9-7,1.

Sampel sebanyak 0,5 g (A) dimasukkan ke dalam gelas piala $600 \mathrm{~mL}$, kemudian ditambah $100 \mathrm{~mL}$ larutan NDS dan dipanaskan pada suhu $105^{\circ} \mathrm{C}$ selama 1 jam. Larutan tersebut kemudian disaring menggunakan cawan kaca masir G3 yang telah ditimbang sebelumnya (B), kemudian residu dibilas menggunakan air panas dan aseton, dan dikeringkan dalam oven suhu $105^{\circ} \mathrm{C}$ selama \pm 4 jam sampai beratnya stabil dan dimasukkan ke dalam desikator dan ditimbang (C). Kadar NDF ditentukan dengan rumus:
$\operatorname{NDF}(\%)=\frac{\mathrm{C}-\mathrm{B}}{\mathrm{A}} \times 100 \%$

Analisis kadar Acid Detergent Fiber (ADF) menggunakan larutan ADS (Acid Detergent Solution). Pembuatan larutan ADS dengan melarutkan 20 g CTAB (Cetyl Trimethyl Ammonium Bromide) ke dalam $27,5 \mathrm{~mL} \mathrm{H}_{2} \mathrm{SO}_{4} 1 \mathrm{~N}$ dan ditambah akuades hingga volumenya menjadi $1 \mathrm{~L}$.

Sampel sebanyak $0,5 \quad \mathrm{~g} \quad$ (A) dimasukkan ke dalam gelas piala $600 \mathrm{~mL}$, kemudian ditambah $100 \mathrm{~mL}$ larutan ADS dan dipanaskan pada suhu $105^{\circ} \mathrm{C}$ selama 1 jam. Larutan tersebut kemudian disaring menggunakan cawan kaca masir G3 yang telah ditimbang sebelumnya (B), kemudian residu dibilas menggunakan air panas dan aseton, dan dikeringkan dalam oven suhu $105^{\circ} \mathrm{C}$ selama \pm 4 jam sampai beratnya stabil dan dimasukkan ke dalam desikator dan ditimbang (C). Kadar ADF ditentukan dengan rumus:

$\operatorname{ADF}(\%)=\frac{C-B}{A} \times 100 \%$

Kadar hemiselulosa dapat ditentukan dengan rumus:

Hemiselulosa $(\%)=\%$ NDF - \% ADF

Analisis selulosa merupakan lanjutan dari analisis ADF. Sampel analisis ADF yang sudah ditimbang $(\mathrm{C})$ ditambah larutan $\mathrm{H}_{2} \mathrm{SO}_{4}$ $72 \%$ sampai terendam selama 3 jam, kemudian disaring menggunakan cawan kaca masir G3. Filtrat kemudian dikeringkan dalam oven pada suhu $105^{\circ} \mathrm{C}$ selama \pm 4 jam sampai beratnya stabil dan dimasukkan ke dalam desikator dan ditimbang (D). Kadar selulosa ditentukan dengan rumus:

Selulosa $(\%)=\frac{C-D}{A} \times 100 \%$

Analisis lignin merupakan lanjutan dari analisis ADF dan residu selulosa. Residu kemudian dikeringkan dalam oven pada suhu 
$105^{\circ} \mathrm{C}$ selama \pm 4 jam sampai beratnya stabil, kemudian dimasukkan ke dalam desikator dan ditimbang (D). Residu yang kering kemudian dimasukkan ke dalam tanur pada suhu $600^{\circ} \mathrm{C}$ selama 2 jam dan dimasukkan ke dalam desikator dan ditimbang (E). Kadar lignin ditentukan dengan rumus:

$\operatorname{Lignin}(\%)=\frac{\mathrm{D}-\mathrm{E}}{\mathrm{A}} \times 100 \%$

\subsection{Analisis Data}

Data yang diperoleh dari hasil pengujian proksimat dan komponen serat dianalisis secara deskriptif menggunakan nilai standar deviasi untuk mengetahui pengaruh perebusan yang dilakukan terhadap sampel Caulerpa sp.

\section{HASIL DAN PEMBAHASAN}

\subsection{Morfologi Rumput Laut Caulerpa \\ sp.}

Rumput laut Caulerpa sp. tergolong rumput laut hijau yang tumbuh dengan akar menancap pada substrat pasir atau menempel pada bebatuan dan termasuk famili Caulerpaceae. Morfologi rumput laut ini adalah thalus berdiameter $\pm 1,4 \mathrm{~mm}$ dengan jumlah ramuli sebanyak 24-31 dan berwarna hijau tua. Rumput laut tersebut memiliki kemiripan ciri morfologi dengan rumput laut Caulerpa lentillifera yang memiliki ramuli membentuk bulatan kecil merapat teratur menutupi percabangan sepanjang $\pm 3-5 \mathrm{~cm}$. Thalus berdiameter 1-2 $\mathrm{mm}$ dan berwarna hijau tua (Kadi, 1996). Menurut Tampubolon et al. (2013), rumput laut Caulerpa lentillifera memiliki thalus dengan cabang bulat yang merambat dan cabang-cabang seperti anggur dengan ramuli sebanyak 17-31 buah dan diameter thalus 1,26 $\mathrm{mm}$, sedangkan rumput laut Caulerpa racemosa memiliki jumlah ramuli sebanyak 8-16 buah dan diameter thalus 2,92 $\mathrm{mm}$. Morfologi rumput laut Caulerpa sp. dapat dilihat pada Gambar 1.
Rumput laut Caulerpa sp. tumbuh bergerombol, sehingga disebut anggur laut. Rumput laut ini memiliki sebutan yang berbeda-beda di setiap daerah, diantaranya di Sulawesi Selatan disebut lawi-lawi, di Bali disebut bulung boni, dan di Jawa disebut latoh. Masyarakat pesisir biasa mengonsumsi rumput laut ini dalam kondisi mentah sebagai lalapan atau urap maupun direbus terlebih dahulu.

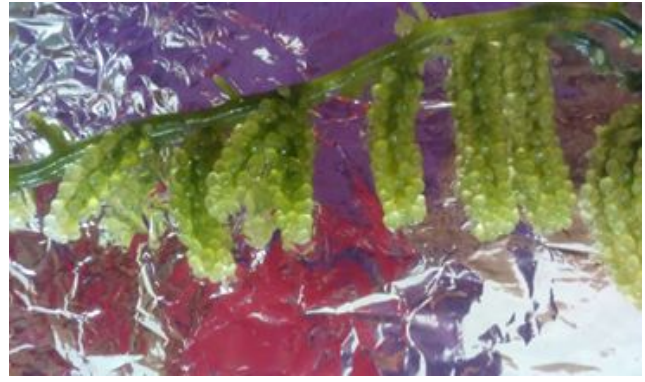

Gambar 1. Morfologi rumput laut Caulerpa sp.

\subsection{Komposisi Kimia Rumput Laut Caulerpa sp.}

Analisis proksimat merupakan suatu metode analisis yang dilakukan untuk mengetahui komposisi kimia dari suatu bahan. Hasil analisis komposisi kimia rumput laut Caulerpa sp. segar dan rebus dibandingkan penelitian Santoso et al. (2006) yang menganalisis komposisi kimia rumput laut Caulerpa racemosa dan Caulerpa sertularoides dari Kepulauan Seribu, Jakarta dapat dilihat pada Tabel 1.

Kadar air rumput laut sebelum direbus $75,11 \pm 0,03 \%$ dan setelah direbus menjadi 78,36 $\pm 0,19 \%$. Menurut Aisyah et al. (2014), perebusan bahan pangan yang mengandung serat pangan tinggi dapat meningkatkan kadar air karena serat pangan memiliki kemampuan menyerap air saat perebusan. Wong dan Cheung (2001) menyatakan bahwa rumput laut banyak mengandung polisakarida non pati atau serat. Menurut Chaidir (2006), serat pangan memiliki daya serap air yang tinggi. Serat pangan memiliki ukuran polimer yang besar, 
Tabel 1. Komposisi kimia rumput laut Caulerpa sp.

\begin{tabular}{|c|c|c|c|c|}
\hline \multirow[b]{2}{*}{$\begin{array}{c}\text { Komposisi Kimia } \\
(\%)\end{array}$} & \multicolumn{2}{|c|}{ Caulerpa sp. } & \multirow{2}{*}{\multicolumn{2}{|c|}{$\begin{array}{c}\text { C. racemosa } \\
\text { C. } \text { sertularoides }^{\text {(a) }}(\mathrm{bb})\end{array}$}} \\
\hline & Segar (bb) & Rebus (bb) & & \\
\hline Air & $75,11 \pm 0,03$ & $78,36 \pm 0,19$ & $88,8 \pm 0,5$ & $82,4 \pm 0,6$ \\
\hline Protein & $3,76 \pm 0,14$ & $3,55 \pm 0,10$ & $1,5 \pm 0,2$ & $3,1 \pm 0,2$ \\
\hline Lemak & $0,37 \pm 0,03$ & $0,41 \pm 0,01$ & $0,5 \pm 0,1$ & $2,3 \pm 0,1$ \\
\hline $\mathrm{Abu}$ & $1,16 \pm 0,11$ & $0,98 \pm 0,11$ & $2,1 \pm 0,2$ & $2,9 \pm 0,2$ \\
\hline $\begin{array}{l}\text { Karbohidrat by } \\
\text { difference }\end{array}$ & $19,6 \pm 0,03$ & $16,69 \pm 0,12$ & 7,1 & 9,3 \\
\hline $\begin{array}{l}\text { Karbohidrat Luff } \\
\text { Schoorl }\end{array}$ & 18,97 & 16,25 & - & - \\
\hline
\end{tabular}

Sumber: (a) Santoso et al. (2006). Keterangan bb: basis basah.

struktur yang kompleks, dan banyak mengandung gugus hidroksil. Santoso et al. (2006) menyatakan bahwa kadar air Caulerpa racemosa $88,8 \pm 0,5 \%$ dan Caulerpa sertularoides $82,4 \pm 0,6 \%$. Hasil kadar air yang diperoleh lebih rendah dibandingkan terjadinya penguapan pada sampel selama penguapan pada sampel selama proses transportasi dari Maluku Tenggara menuju Bogor. Transportasi dapat memicu proses transpirasi, sehingga mempercepat proses penguapan air yang menyebabkan rendahnya kadar air suatu bahan.

Perebusan selama 5 menit pada suhu $90^{\circ} \mathrm{C}$ tidak menyebabkan perubahan kadar protein, karena pada proses perebusan tidak terjadinya perubahan stukutr protein baik dari protein primer hingga protein tersier. Santoso et al. (2006) menyatakan bahwa kadar protein Caulerpa racemosa $1,5 \pm 0,2 \%$ dan

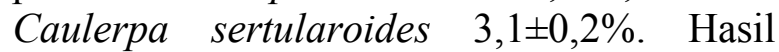
kadar protein yang diperoleh lebih tinggi dibandingkan literatur. Protein tersusun atas beberapa asam amino dengan ikatan peptida. Menurut Ratana dan Chirapart (2006), tinggi rendahnya kadar protein dapat dihubungkan dengan asam amino yang terkandung dalam bahan, semakin tinggi kandungan asam amino, maka kadar protein yang terkandung juga semakin tinggi. Kandungan protein yang berbeda pada rumput laut disebabkan oleh perbedaan spesies, musim, dan kondisi geografis.
Perebusan selama 5 menit pada suhu $90^{\circ} \mathrm{C}$ tidak menyebabkan perubahan kadar lemak secara signifikan, hal ini diakrenakan waktu perebusan yang tidak terlalu lama tidak banyak mengubah stukutur lemak dan turunan mikromolekulnya. Santoso et al. (2006) menyatakan bahwa kadar lemak Caulerpa sertularoides 2,3 $\pm 0,1 \%$. Hasil kadar lemak yang diperoleh lebih rendah dibandingkan literatur. Rendahnya kadar lemak disebabkan oleh kandungan asam lemak pada Caulerpa sp. yang lebih rendah daripada Caulerpa sertularoides. Kadar lemak tersusun atas beberapa jenis asam lemak. Menurut Santoso et al. (2004), asam lemak Caulerpa sertularoides cukup tinggi, diantaranya asam lemak yang paling dominan adalah asam palmitat $45,3 \pm 1,1 \%$, linolenat $13,7 \pm 0,2 \%$, heptadekanoat $7,9 \pm$ $0,1 \%$, dan oleat $7,1 \pm 0,2 \%$. Menurut Wong dan Cheung (2001), kadar lemak pada rumput laut tergolong rendah.

Perebusan selama 5 menit pada suhu $90^{\circ} \mathrm{C}$ tidak menyebabkan perubahan kadar abu. Santoso et al. (2006) menyatakan bahwa kadar abu Caulerpa racemosa $2,1 \pm 0,2 \%$ dan Caulerpa sertularoides 2,9 $\pm 0,2 \%$. Bahan pangan terdiri atas $96 \%$ zat organik dan air, serta $4 \%$ terdiri atas unsur mineral atau zat anorganik. Abu merupakan zat anorganik sisa hasil pembakaran suatu bahan organik. Menurut Ratana dan Chirapart (2006), tinggi rendahnya kadar abu dapat dihubungkan 
dengan jumlah unsur mineral yang terkandung dalam bahan, semakin tinggi kandungan mineralnya, maka kadar abu yang terkandung semakin tinggi. Menurut Ruperez (2002), kandungan mineral rumput laut dipengaruhi oleh spesies, faktor fisiologis, dan kondisi geografis. Kandungan abu rumput laut lebih tinggi dibandingkan tanaman air, misalnya genjer. Nurjanah et al. (2014) menyatakan bahwa kadar abu tanaman genjer $0,70 \pm 0,14 \%$ (berat basah).

Perhitungan kadar karbohidrat umumnya dengan metode by difference. Metode ini memiliki kelemahan hasil yang kurang akurat, sehingga diperlukan pengujian dengan metode Luff Schoorl. Hasil karbohidrat metode by difference sebelum direbus $19,6 \pm 0,03 \%$ dan setelah direbus menjadi $16,69 \pm 0,12 \%$. Hasil kadar karbohidrat metode Luff Schoorl sebelum direbus $18,97 \%$ dan setelah direbus menjadi 16,25\%. Metode Luff Schoorl memiliki kadar karbohidrat yang lebih rendah dibandingkan metode by difference. Menurut Whelan dan Pirt (2006), metode by difference memiliki kesalahan positif karena tidak dapat membedakan komponen non karbohidrat, diantaranya asam organik, tanin, dan lignin, sehingga komponen tersebut ikut terhitung sebagai karbohidrat. Kadar karbohidrat yang dianalisis dengan metode Luff Schoorl memperoleh hasil yang lebih rendah dibandingkan metode by difference, karena adanya tahapan hidrolisis pada metode Luff Schoorl menggunakan $\mathrm{HCl} 25 \%$ dan dilakukan pemanasan pada suhu $70^{\circ} \mathrm{C}$ selama 10 menit.

Penurunan kadar karbohidrat setelah perebusan dapat disebabkan komponen karbohidrat salah satunya pati mengalami gelatinisasi saat perebusan pada suhu $90^{\circ} \mathrm{C}$ selama 5 menit dan beberapa komponen karbohidrat yang larut dalam media air, diantaranya pektin, gum, mucilage, dan komponen monosakarida lainnya. Santoso et al. (2006) menyatakan bahwa kadar karbohidrat by difference Caulerpa racemosa 7,1\% dan Caulerpa sertularoides 9,3\%. Hasil kadar karbohidrat yang diperoleh lebih tinggi dibandingkan literatur. Menurut penelitian Marinho-Soriano et al. (2006), kandungan karbohidrat rumput laut dipengaruhi temperatur, salinitas, dan intensitas cahaya matahari.

\subsection{Karakteristik Serat Rumput Laut Caulerpa sp.}

Serat adalah bagian dari komponen tumbuhan yang tidak dapat diserap oleh tubuh. Serat umumnya terbagi menjadi dua, yakni serat pangan dan serat kasar. Serat pangan merupakan serat yang tidak dapat dicerna oleh enzim pencernaan manusia. Serat pangan berdasarkan kelarutannya terhadap air terbagi dua, yakni serat pangan larut (soluble dietary fiber/SDF) yang terdiri dari pektin dan turunannya, gum, serta mucilage dan serat pangan tidak larut (insoluble dietary fiber/IDF) yang terdiri dari selulosa, hemiselulosa, dan lignin. Serat pangan tersusun atas polisakarida dengan ikatan $\beta$ (1-4) yang tidak dapat dicerna oleh enzim amilase yang disekresikan oleh kelenjar saliva dan pankreas, namun dapat dimetabolisme oleh bakteri yang terdapat pada usus besar. Serat kasar adalah komponen sisa hasil hidrolisis dengan asam kuat selanjutnya dihidrolisis dengan basa kuat sehingga terjadi kehilangan selulosa sekitar 50\% dan hemiselulosa 85\% (Wildman dan Medeiros 2000). Hasil komposisi serat Caulerpa sp. segar dan rebus dibandingkan beberapa penelitian yang menganalisis komposisi serat rumput laut Caulerpa racemosa, Caulerpa sertularoides, dan Caulerpa lentillifera dapat dilihat pada Tabel 2.

Serat pangan berperan dalam metabolisme glukosa dan lemak, memperlancar buang air besar, menstimulasi aktivitas metabolisme bakteri, dan detoksifikasi terhadap zat yang berada dalam kolon. Hasil serat pangan total sebelum direbus $43,97 \pm 0,38 \%$ dan setelah direbus menjadi $40,17 \pm 0,52 \%$. Perebusan selama 5 menit pada suhu $90^{\circ} \mathrm{C}$ menyebabkan penurunan 
Tabel 2. Komposisi serat rumput laut Caulerpa sp.

\begin{tabular}{lccccc}
\hline \multirow{2}{*}{ Komposisi serat (\%) } & \multicolumn{2}{c}{ Caulerpa sp } & \multirow{2}{*}{$C R^{\text {(a) }}$} & \multirow{2}{*}{$C S^{\text {(a) }}$} & \multirow{2}{*}{$C L^{\text {(b) }}$} \\
\cline { 2 - 4 } & \multicolumn{1}{c}{ Segar } & Rebus & & & \\
\hline Serat pangan total & $43,97 \pm 0,38$ & $40,17 \pm 0,52$ & $64,9 \pm 4,9$ & $61,8 \pm 1,1$ & $32,99 \pm 2,07$ \\
Serat pangan tak larut & $22,88 \pm 0,49$ & $24,13 \pm 0,14$ & $64,1 \pm 3,8$ & $60,1 \pm 0,7$ & $15,78 \pm 1,20$ \\
Serat pangan larut & $21,09 \pm 0,13$ & $16,04 \pm 0,63$ & $0,9 \pm 0,1$ & $1,8 \pm 0,9$ & $17,21 \pm 0,87$ \\
Serat kasar & $2,47 \pm 0,03$ & $1,62 \pm 0,10$ & $C L^{(b)}$ & $C R^{(\mathrm{c})}$ & $C L^{(\mathrm{d})}$ \\
& & & $1,91 \pm 0$ & $8,43 \pm 2,38$ & $3,17 \pm 0,21$ \\
\hline
\end{tabular}

$\mathrm{CR}=$ Caulerpa racemosa $; \mathrm{CS}=$ Caulerpa sertularoides; dan $\mathrm{CL}=$ Caulerpa lentillifera

Sumber: (a) Santoso et al. (2004); (b) Matanjun et al. (2009); (c) Ma'ruf et al. (2013);

(d) Ratana-Arporn dan Chirapart (2006).

kadar serat pangan total. Kadar serat pangan total diperoleh dari hasil penjumlahan serat pangan larut dan tak larut. Menurut hasil penelitian Pangastuti et al. (2013) bahwa serat pangan total pada tepung kacang merah mengalami penurunan setelah dilakukan perebusan selama 90 menit. Kadar serat pangan total rumput laut segar tergolong tinggi, yakni 43,97\%. Menurut Wong dan Cheung (2001), rumput laut banyak mengandung polisakarida non pati atau serat.

Menurut Matanjun et al. (2009), kandungan serat Caulerpa lentillifera dari perairan Semporna, Malaysia yakni serat pangan total $32,99 \pm 2,07 \%$, serat pangan larut $17,21 \pm 0,87 \%$, dan serat pangan tak larut $15,78 \pm 1,20 \%$. Kadar serat pangan total, serat pangan larut, dan serat pangan tak larut Caulerpa sp. yang diperoleh dari perairan Tual, Maluku Tenggara lebih tinggi daripada Caulerpa lentillifera dari perairan Semporna, Malaysia.

Ortiz et al. (2006) menyatakan bahwa kandungan serat rumput laut di-pengaruhi oleh musim, lokasi geografi, jenis spesies, umur panen, dan kondisi lingkungan.

Serat pangan total, dibagi dua kelompok yakni serat pangan larut dan tak larut. Serat tak larut air yaitu serat yang tidak dapat larut dalam air dan juga dalam saluran pencernaan. Kadar serat tak larut sebelum direbus $22,88 \pm 0,49 \%$ dan setelah direbus menjadi 24,13 $\pm 0,14 \%$. Perebusan menyebabkan pembentukan pati tak tercerna, mengingat rumput laut Caulerpa sp. banyak mengandung karbohidrat, salah satunya adalah kandungan pati. Menurut Widayanti et al. (2013), kadar pati rumput laut Gracilaria sp. dari perairan Serangan, Bali $15,42 \%$.

Menurut Nugent (2005), pati tak tercerna memiliki sifat tahan terhadap hidrolisis enzim pencernaan dan tidak dapat tercerna dalam usus halus sehingga digolongkan sebagai serat pangan. Menurut Nyman (1995), pemasakan dengan panas dapat meningkatkan serat tak larut akibat pembentukan pati tak tercerna. Menurut Asp (1995), pati atau produk degradasi pati yang tidak dapat dicerna oleh usus manusia disebut pati resisten atau resistant starch (RS).

Pembentukan resistant starch dalam bahan pangan dapat disebabkan oleh pemanasan. Resistant starch ini tahan terhadap dispersi dalam air mendidih dan tidak dapat dihidrolisis oleh enzim amilase, pankreatin, dan pullulanase, tetapi dapat didispersi dalam larutan $\mathrm{KOH}$ dan dapat dihidrolisis oleh enzim amiloglukosidase. Pengujian serat pangan metode Van Soest (1963) tidak menggunakan enzim amiloglukosidase, sehingga kemungkinan RS yang terbentuk selama perebusan tidak dapat terhidrolisis, dan terukur sebagai serat pangan tak larut. Klasifikasi pati resisten dapat dilihat pada Tabel 3. 
Tabel 3 Klasifikasi pati resisten.

\begin{tabular}{ll}
\hline $\begin{array}{c}\text { Jenis Pati } \\
\text { Resisten }\end{array}$ & \multicolumn{1}{c}{ Definisi } \\
\hline RS-1 & $\begin{array}{l}\text { Pati yang secara fisik sulit } \\
\text { dicerna (ukurannya besar) }\end{array}$ \\
RS-2 & Granula pati resisten \\
RS-3 & Pati retrogradasi (resisten \\
& karena proses pengolahan) \\
RS-4 & Pati termodifikasi \\
\hline
\end{tabular}

Sumber: Nugent (2005).

Kadar serat pangan larut sebelum direbus $21,09 \pm 0,13 \%$ dan setelah direbus menjadi $16,04 \pm 0,63 \%$. Serat pangan larut air yaitu serat yang dapat larut dalam air dan larut dalam saluran pencernaan, namun dapat membentuk gel dengan cara menyerap air. Kadar serat kasar rumput laut sebelum direbus $2,47 \pm 0,03 \%$ dan setelah direbus menjadi $1,62 \pm 0,1 \%$. Menurut Kusumawati et al. (2012), kadar serat kasar tepung biji nangka mengalami penurunan setelah dilakukan blanching pada suhu $80^{\circ} \mathrm{C}$ selama 10 menit. Penurunan serat kasar dipengaruhi oleh suhu dan lama blanching. Matanjun et al. (2009) menyatakan bahwa serat kasar Caulerpa lentillifera $1,91 \pm 0 \%$. Ratana dan Chirapart (2006) menyatakan bahwa serat kasar Caulerpa lentillifera 3,17 $\pm 0,21 \%$. Serat kasar Caulerpa sp. yang diperoleh dari perairan Tual, Maluku Tenggara lebih tinggi daripada Caulerpa lentillifera dari perairan Semporna, Malaysia dan lebih rendah daripada Caulerpa lentillifera dari perairan Amphor-BanLam, Petchburi. Kandungan serat kasar yang berbeda pada rumput laut disebabkan oleh perbedaan habitat, musim, dan jenis spesies.

\subsection{Komponen Serat Rumput Laut Caulerpa sp.}

Polisakarida rumput laut tersusun dari hidrokoloid penyusun dinding sel dan bahan pengisi ruang antara sel, misalnya karaginan dan agar-agar. Menurut Vera et al. (2011), jenis rumput laut hijau lebih banyak mengandung polisakarida xilan dan ulvan.
Menurut Wong dan Cheung (2001), perbedaan kandungan polisakarida pada rumput laut disebabkan oleh kadar sulfat pada struktur utama monosakarida penyusunnya dan jenis spesies rumput laut. Hasil komponen serat Caulerpa sp. segar dan rebus dibandingkan penelitian Santi et al. (2012) mengenai komponen serat Caulerpa crassa dan Ulva lactuca dapat dilihat pada Tabel 4.

Sampel Caulerpa sp. yang digunakan untuk pengujian komponen serat diambil pada bulan Maret atau musim pancaroba, yakni musim peralihan dari musim hujan menuju musim kemarau. Hasil pada Tabel 4 menunjukkan kadar selulosa, hemiselulosa, lignin Caulerpa sp. rebus apabila dijumlahkan kadarnya, melebihi kadar serat pangan total Caulerpa sp. rebus yang diambil pada bulan Desember yang tersaji pada Tabel 2 . Perbedaan musim dapat mempengaruhi kadar serat pangan total yang terkandung pada rumput laut, ketika musim hujan maka intensitas cahaya berkurang, sehingga menurunkan laju fotosintesis dan sintesis karbohidrat. Rumput laut Caulerpa sp. yang diambil pada bulan Maret memiliki kadar serat pangan total lebih tinggi dibandingkan pengambilan bulan Desember, kemungkinan karena pada bulan Maret tergolong musim kemarau dan rumput laut akan lebih aktif melakukan fotosintesis dibandingkan bulan Desember, sehingga kadar serat pangan total yang terkandung lebih tinggi.

Metode yang digunakan untuk menentukan komponen serat (selulosa, hemiselulosa, dan lignin) adalah metode Van Soest 1963. Menurut Jung (1997), metode Van Soest merupakan metode pengujian kimia untuk mengukur kadar komponen serat menggunakan pelarut detergen. Neutral Detergent Fiber (NDF) merupakan semua komponen karbohidrat struktural yang terkandung pada dinding sel tumbuhan, meliputi selulosa, hemiselulosa, dan lignin. Hal ini sangat berbeda dengan pengujian serat pangan multi enzim yang hanya menghitung serat pangan terlarut dan tidak terlarut. 
Tabel 4 Komponen serat rumput laut Caulerpa sp.

\begin{tabular}{lcccc}
\hline \multirow{2}{*}{$\begin{array}{c}\text { Komponen serat } \\
(\%)\end{array}$} & \multicolumn{2}{c}{ Caulerpa sp. } & \multirow{2}{*}{ Caulerpa crassa $^{\text {(a) }}$} & Ulva lactuca $^{\text {(a) }}$ \\
\cline { 2 - 4 } & Segar & Rebus & & 19,58 \\
Selulosa & $8,70 \pm 0,32$ & $22,61 \pm 0,76$ & 25,50 & 16,42 \\
Hemiselulosa & $6,40 \pm 0,08$ & $17,80 \pm 0,54$ & 43,73 & 2,9 \\
Lignin & $2,08 \pm 0,32$ & $2,23 \pm 0,81$ & 4,00 & \\
\hline
\end{tabular}

Sumber: (a) Santi et al. (2012).

Kadar NDF rumput laut sebelum direbus $17,7 \pm 0,19 \%$ dan setelah direbus menjadi 42,65 $\pm 0,48 \%$. Acid Detergent Fiber (ADF) merupakan komponen yang terdiri dari selulosa dan lignin. ADF juga didefinisikan banyaknya fraksi yang tidak terlarut setelah proses pelarutan dengan larutan Acid Detergent Solution (ADS). Kadar ADF rumput laut sebelum direbus $11,3 \pm 0,25 \%$ dan setelah direbus menjadi $24,85 \pm 0,96 \%$.

Selulosa merupakan komponen struktural utama dinding sel. Selulosa dapat dihidrolisis menggunakan enzim selulase. Enzim tersebut tidak dimiliki oleh tubuh manusia, sehingga selulosa tidak dapat dicerna oleh pencernaan tubuh manusia. Kadar selulosa rumput laut sebelum direbus $8,7 \pm 0,32 \%$ dan setelah direbus menjadi $22,61 \pm 0,76 \%$. Yuanita (2006) menyatakan bahwa kadar selulosa kacang panjang meningkat setelah direbus pada suhu $100^{\circ} \mathrm{C}$ selama 5 menit. Perebusan menyebabkan pembengkakan dinding sel, sehingga terjadi pembebasan pati dan lipid dan terjadi pembentukan senyawa kompleks hasil ikatan pati dan lipid yang bersifat sebagai pati tidak tercerna. Menurut Nyman (1995), perebusan dapat meningkatkan kadar pati tak tercerna yang terukur sebagai selulosa, sehingga kadar selulosa meningkat. Menurut Santi et al. (2012), kadar selulosa rumput laut Caulerpa crassa 25,5\% dan Ulva lactuca 19,58\%. Kadar selulosa Caulerpa sp. yang diperoleh dari perairan Tual, Maluku Tenggara lebih rendah daripada Caulerpa crassa dan Ulva lactuca dari perairan Ujung Genteng, Sukabumi. Menurut Diharmi et al.
(2011), perbedaan kadar selulosa pada rumput laut dipengaruhi oleh spesies rumput laut, habitat, dan musim.

Hemiselulosa merupakan polisakarida heteropolimer yang memiliki rantai cabang tidak seragam dan merupakan komponen penyusun dinding sel yang saling berikatan dengan selulosa dan lignin. Hemiselulosa juga larut dengan pelarut deterjen asam. Hemiselulosa dapat dihidrolisis menggunakan enzim hemiselulase (xylanase). Enzim tersebut tidak dimiliki oleh tubuh manusia, sehingga hemiselulosa tidak dapat dicerna oleh pencernaan tubuh manusia. Kadar hemiselulosa sebelum direbus $6,4 \pm 0,08 \%$ dan setelah direbus menjadi $17,8 \pm 0,54 \%$. Kadar hemiselulosa diperoleh dari selisih NDF dan ADF. Yuanita (2006) menyatakan bahwa hemiselulosa tahan terhadap suhu pemasakan dengan media air pada $\mathrm{pH}$ netral, sehingga saat perebusan hemiselulosa tidak terhidrolisis. Hemiselulosa berikatan kuat dengan komponen lignin, sehingga mempersulit proses hidrolisis. Hemiselulosa dapat terhidrolisis pada suhu pemanasan $121^{\circ} \mathrm{C}$ dengan pelarut asam sulfat. Hemiselulosa memiliki kemampuan yang kuat dalam mengikat molekul air selama perebusan. Molekul air yang terikat dengan hemiselulosa akan menghalangi afinitas asam, sehingga hemiselulosa tidak terhidrolisis selama proses perebusan.

Menurut Santi et al. (2012), kadar hemiselulosa rumput laut Caulerpa crassa 43,73\% dan Ulva lactuca 16,42\%. Kadar hemiselulosa Caulerpa sp. yang diperoleh dari perairan Tual, Maluku Tenggara lebih rendah daripada Caulerpa crassa dan Ulva 
lactuca dari perairan Ujung Genteng, Sukabumi. Kandungan hemiselulosa yang berbeda pada rumput laut dipengaruhi oleh spesies rumput laut, habitat, dan musim.

Lignin merupakan salah satu polimer fenilpropanoid yang sulit dirombak atau dicerna, karena strukturnya yang heterogen dan sangat kompleks. Lignin tahan terhadap hidrolisis asam kuat atau alkali dan tidak terdegradasi oleh bakteri dalam kolon, serta tahan terhadap degradasi kimia maupun degradasi enzimatik. Perebusan selama 5 menit pada suhu $90^{\circ} \mathrm{C}$ tidak menyebabkan perubahan kadar lignin. Menurut Santi et al. (2012), kadar lignin Caulerpa crassa 4,00\% dan Ulva lactuca 2,9\%. Kadar lignin Caulerpa sp. yang diperoleh dari perairan Tual, Maluku Tenggara lebih rendah daripada Caulerpa crassa dan Ulva lactuca dari perairan Ujung Genteng, Sukabumi. Menurut Burtin (2003), rumput laut bukan sebagai sumber lignin. Kandungan lignin yang berbeda pada rumput laut dipengaruhi oleh spesies rumput laut, habitat, dan musim.

\section{KESIMPULAN}

Rumput laut Caulerpa sp. dapat dijadikan sebagai salah satu alternatif sumber serat. Perebusan pada suhu $90^{\circ} \mathrm{C}$ selama 5 menit tidak mempengaruhi kadar lignin. Perebusan meningkatkan serat pangan tak larut $1,25 \%$, selulosa $13,91 \%$, hemiselulosa $11,4 \%$, dan menurunkan kadar serat pangan total $3,8 \%$, serat pangan larut $5,05 \%$, dan serat kasar $0,85 \%$

\section{DAFTAR PUSTAKA}

Aisyah, Y., Radiansyah, dan Muhaimin. 2014. Pengaruh pemanasan terhadap aktivitas pada beberapa jenis sayuran. J. Teknologi dan Industri Pertanian Indonesia, 6(2):1-6.

Anderson, J.W., P. Baird, D. Jr, S. Ferreri, M. Knudtson, A. Koraym, V. Waters, and C.L. Williams. 2009. Health benefits of dietary fiber. Internasional Life Sciences Institute, 67(4):188-205. Association of Official Analitycal Chemist (AOAC). 2005. Official methods of analy. of the association of official anality. of chemists. AOAC. US. 80p.

Asp, N.G., T.F. Schweizer, D.A.T. Southgate, and O. Theander. 1992. Dietary fiber analysis. Springer. London. 21p.

Asp, N.G. 1995. Classification and method of food carbohydrates as related to nutrional effects. American J. Clinical Nutrition 61:930-937.

Atmadja, W.S. dan F.P.V.R. Willem. 2011. Checklist of the seaweed species biodiversity of Indonesia. LIPI. Jakarta. 260p.

Badan Pusat Statistik Maluku Tenggara (BPS). 2013. Maluku tenggara dalam angka 2013. Badan Pusat Statistik. Maluku Tenggara. 30hlm.

Burtin, P. 2003. Nutritional value of seaweeds. J. of Environmental, Agriculture Food Chemis., 2(4):498-503.

Chaidir, A. 2006. Kajian rumput laut sebagai sumber serat alternatif minuman berserat. IPB. Bogor. 45hlm.

Departemen Kesehatan RI (DEPKES). 2008. Laporan hasil riset kesehatan dasar (RISKESDAS) Nasional 2007. Pusat Penelitian dan Pengembangan Depart. Kesehatan. Jakrata. 20hlm.

Diachanty, S., Nurjanah, dan A. Abdullah. 2017. Aktivitas antioksidan berbagai jenis rumput laut coklat Dari perairan kepulauan seribu. JPHPI., 20(2):305318.

Diharmi, A., D. Fardiaz, N. Andarwulan, dan E.S. Heruwati. 2011. Karakteristik komposisi kimia rumput laut merah (Rhodophyceae) Eucheuma spinosum yang dibudidayakan dari perairan Nusa Penida, Takalar, dan Sumenep. Berkala Perikanan Terubuk, 39(2): 61-66.

Dolorosa, M.T., Nurjanah, S. Purwaningsih, E. Anwar, dan T. Hidayat. 2017. Kandungan senyawa bioaktif bubur 
rumput laut Sargassum plagyophyllum dan Eucheuma cottonii sebagai bahan baku krim pencerah kulit. JPHPI., 20(3):633-644.

Jung, G.H.J. 1997. Analysis of forage fiber and cell walls in ruminant nutrition. $J$. Nutritional, 127:810-813.

Kadi, A. 1996. Pengenalan jenis algae hijau (Chlorophyta). Puslitbang Oseanologi LIPI. Jakarta. 23p.

Kusumawati, D.D., B.S. Amanto, dan D.R.A. Muhammad. 2012. Pengaruh perlakuan pendahuluan dan suhu pengeringan terhadap sifat fisik, kimia, dan sensori tepung biji nangka (Artocarpus heterophyllus). J. Teknosains Pangan, 1(1):41-48.

Luthfiyana, N., Nurjanah, M. Nurilmala, E. Anwar, dan T. Hidayat. 2016. Rasio bubur rumput laut E. cottonii dan Sargassum sp. sebagai formula krim tabir surya. JPHPI.,, 19(3):183-195.

Ma'ruf, W.F., R. Ibrahim, E.N. Dewi, E. Susanto, dan U. Amalia. 2013. Profil rumput laut $C$. racemosa dan $G$. verrucosa sebagai edible food. $J$. Saintek Perikanan, 9(1):68-74.

Maharani, F. Nurjanah, R. Suwandi, E. Anwar, dan T. Hidayat. 2017. Kandungan senyawa bioaktif rumput laut Padina australis dan Eucheuma cottonii sebagai bahan baku krim tabir surya. JPHPI., 20(1):10-17

Marinho-Soriano, E., P.C. Fonseca, M.A.A. Carneiro, and W.S.C. Moreira. 2006. Seasonal variation in the chemical composition of two tropical seaweeds. Bioresource Technology, 97:2402-2406.

Matanjun, P., S. Mohamed, N.M. Mustapha, and K. Muhammad. 2009. Nutrient content of tropical edible seaweeds, E. cottonii, $C$. lentillifera and $S$. polycystum. J. of Applied Phycology, 21:75-80.

Nufus, C., Nurjanah, Abdullah, A. 2017. Karakteristik rumput laut hijau dari perairan kepulauan seribu dan sekotong nusa tenggara barat sebagai antioksidan. JPHPI., 20(3):620-632.

Nugent, A.P. 2005. Health properties of resistant starch. Bulletin Foundation Nutrition, 30:27-54.

Nurjanah, A. Abdullah, dan C. Nufus. 2018. Karakteristik sediaan garam Ulva lactuca dari perairan Sekotong Nusa Tenggara Barat bagi pasien hipertensi. JPHPI., 21(1):109-117.

Nurjanah, M. Nurilmala, E. Anwar, N. Luthfiyana, dan T. Hidayat. 2017. Identification of Bioactive Compounds of Seaweed Sargassum sp. and $E$. cottonii Doty as a Raw Sunscreen Cream. Pakistan Academy of Sciences B. Life and Environmental Sciences, 54(4):311-31.

Nurjanah, M., Nurilmala, T., Hidayat, F., Sudirdjo. 2016. Characteristics of seaweed as raw materials for cosmetics. Aquatic Procedia, 7:177180.

Nurjanah, A.M., Jacoeb, R. Nugraha, M. Permatasari, dan T.K.A. Sejati. 2014. Perubahan komposisi kimia, aktivitas antioksidan, vitamin $\mathrm{C}$ dan mineral tanaman genjer (Limnocharis flava) akibat pengukusan. J. Inovasi dan Kewirausahaan, 3(3):185-195.

Nyman, M. 1995. Effects of processing on dietary fibre in vegetables. European J. Clinical Nutrition, 49(3):215-218.

Ortiz, J., N. Romero, P. Robert, J. Araya, H.J. Lopez, C. Bozzo, E. Navarrete, A. Osorio, and A. Rios. 2006. Dietary fiber, amino acid, fatty acid and tocopherol contents of the edible seaweeds Ulva lactuca and Durvillaea antarctica. Food Chemistry, 99:98-104.

Pangastuti, H.A., D.R. Affandi, dan D. Ishartani. 2013. Karakterisasi sifat fisik dan kimia tepung kacang merah (Phaseolus vulgaris L.) dengan beberapa perlakuan pendahuluan. $J$. Teknosains Pangan, 2(1):20-29. 
Putera, B.A. 2015. Aktivitas antioksidan rumput laut Caulerpa sp. segar dan rebus. Skripsi. Institut Pertanian Bogor. Bogor. 48p.

Ratana-Arporn, P. and A. Chirapart. 2006. Nutritional evaluation of tropical green seaweeds Caulerpa lentillifera and Ulva reticulate. Kasetsart J. (National Science), 40:75-83.

Riyanto, B. dan M. Wilakstanti. 2006. Cookies berkadar serat tinggi substitusi tepung ampas rumput laut dari pengolahan agar-agar kertas. JPHPI., 9(1): 49-60.

Ruperez, P. 2002. Mineral content of edible marine seaweeds. Food Chemistry, 79: 23-26.

Sanchez, M.D.J., C. Lopez , H.J. Lopez, and L.P. Paseiro. 2004. Fatty acids, total lipid, protein and ash contens of processed edible seaweeds. Food Chemistry, 85:439-444.

Santi, R.A., T.C. Sunarti, D. Santoso, dan D.A. Triwisari. 2012. Komposisi kimia dan profil polisakarida rumput laut hijau. J. Akuatika, 3(2):105-114.

Santoso, J., S. Gunji, Y. Yoshie, and T. Suzuki. 2006. Mineral contents of Indonesian seaweeds and mineral solubility affected by basic cooking. Food Science Tec., 12(1):59-66.

Santoso, J., Y. Yoshie, and T. Suzuki. 2004. Mineral, fatty acid and dietary fiber compositions in several Indonesian seaweeds. J. Ilmu-Ilmu Perairan dan Perikanan Indonesia, 11(1):45-51.

Sulaeman, A., F. Anwar, Rimbawan, dan S.A. Marliyati. 1993. Metode analisis komposisi zat gizi makanan. IPB Press. Bogor. 33p.

Tampubolon, A., G.S. Gerung, dan B. Wagey. 2013. Biodersivitas alga makro di Lagun Pulau Pasige, Kecamatan Tagulandang, Kabupaten Sitaro. J. Pesisir dan Laut Tropis, 2(1):35-43.
Van Soest, P.J. 1963. Use of detergent in the analysis of fibrous feed, II. A rapid method for the determination of fiber and lignin. J. Association Official Agriculture Chemistry, 46(5):829835.

Vera, J., J. Castro, A. Gonzalez, and A. Moenne. 2011. Seaweed polysaccharides and derived oligosaccharides stimulate defense responses and protection against pathogens in plants. Marine Drugs, 9:2514-2525.

Whelan, W.J., and Pirt. 2006. The determination of starch by acid hydrolysis. J. of the Science of Food and Agriculture, 2(5):224-228.

Widayanti, N.P., W.S. Rita, dan Y. Ciawi. 2013. Pengaruh konsentrasi ammonium sulfat $\left(\left(\mathrm{NH}_{4}\right)_{2} \mathrm{SO}_{4}\right)$ sebagai sumber nitrogen tehadap produksi bioetanol berbahan baku Gracilaria sp.. J. Kimia, 7(1):1-10.

Wildman, R.E.C. and D.M. Medeiros. 2000. Advanced human nutrition. CRC Press. Florida. 240p.

Wong, K.H. and P.C.K. Cheung. 2001. Nutritional evaluation of some subtropical red and green seaweeds. $2^{\text {nd }} \mathrm{ed}$. Invitro protein digestibility and amino acid profiles of protein concentrates. Food Chem., 72:11-17.

Yanuarti, R., Nurjanah, Anwar, E., Hidayat, T. 2017. Profil fenolik dan aktivitas antioksidan dari ekstrak rumput laut Turbinaria conoides dan Eucheuma cottonii. JPHPI., 20(2):230-237

Yuanita, L. 2006. The effect of pectic substances, hemicellulose, lignin and cellulose content to the percentage of bound iron by dietary fiber macromolecules: acidity and length boiling time variation. Indonesian $J$. Chemistry, 6(3):332-337.
Diterima
: 22 Maret 2017
Direview
: 19 Desember 2017
Disetujui : 23 Maret 2018 